Alexandre Braga Libório

Danilo Teixeira Noritomi

Tacyano Tavares Leite

Candice Torres de Melo Bezerra

Evandro Rodrigues de Faria

John A. Kellum

\section{Erratum to: Increased serum bicarbonate in critically ill patients: a retrospective analysis}

Published online: 12 February 2015

(C) Springer-Verlag Berlin Heidelberg and ESICM 2015

The online version of the original article can be found under doi:10.1007/s00134-015-3649-9.

A. B. Libório ( $)$ T. T. Leite - C. T. de Melo Bezerra

Department of Clinical Medicine, Universidade Federal do Ceará, Av. Abolição, 4043 Ap 1203, Ed. Jangada, Fortaleza,

CE CEP 60165-082, Brazil

e-mail: alexandreliborio@yahoo.com.br

Tel.: 558599987995

\section{T. Noritomi}

Unidade de Terapia Intensiva, Hospital Paulistano,

São Paulo, SP, Brazil

E. R. de Faria

Pronefron Section, Fresenius Medical Group, Fortaleza, CE, Brazil

\section{J. A. Kellum}

Department of Critical Care Medicine, The Center for Critical Care Nephology, University of Pittsburgh School of Medicine, University of Pittsburgh Medical Center, Pittsburgh, PA, USA

\section{Erratum to: Intensive Care Med DOI 10.1007/s00134-015-3649-9}

Owing to a technical fault in the typesetting process, some of the data from Table 2 were omitted from the PDF version of the article. The table is reproduced here in full. The publisher apologizes for this error and any inconvenience caused.

Table 2 Association of maximum serum bicarbonate during ICU stay with in-hospital mortality

\begin{tabular}{|c|c|c|c|c|c|c|c|}
\hline & \multirow{2}{*}{$\begin{array}{l}\text { Univariate } \\
\text { analysis } \\
\text { OR }(95 \% \mathrm{CI})\end{array}$} & \multicolumn{2}{|c|}{ Model 1} & \multicolumn{2}{|c|}{ Model 2} & \multicolumn{2}{|c|}{ Model 3} \\
\hline & & $\beta$ & OR $(95 \% \mathrm{CI})$ & $\beta$ & OR $(95 \% \mathrm{CI})$ & $\beta$ & OR $(95 \%$ CI $)$ \\
\hline $\begin{array}{l}\text { Maximum serum } \\
\text { bicarbonate } \\
25-30 \mathrm{mEq} / \mathrm{L}\end{array}$ & Ref. & Ref. & Ref. & Ref. & Ref. & Ref. & Ref. \\
\hline $\begin{array}{l}\text { Maximum serum } \\
\text { bicarbonate under } \\
25 \mathrm{mEq} / \mathrm{L} \text {, per } \\
\text { each } 5-\mathrm{mEq} / \mathrm{L}\end{array}$ & $2.332(2.104-2.583)$ & 0.805 & $2.238(2.091-2.560)$ & 0.778 & $2.179(1.954-2.411)$ & 0.569 & $1.770(1.550-2.015)$ \\
\hline $\begin{array}{l}\text { Maximum serum } \\
\text { bicarbonate above } \\
30 \mathrm{mEq} / \mathrm{L} \text {, per } \\
\text { each } 5-\mathrm{mEq} / \mathrm{L}\end{array}$ & $1.297(1.235-1.362)$ & 0.265 & $1.304(1.211-1.353)$ & 0.194 & $1.215(1.156-1.293)$ & 0.191 & $1.211(1.116-1.316)$ \\
\hline
\end{tabular}

Model 1 adjusts for age, gender. Model 2 adjusts for covariate in model 1 and simplified acute physiology score (SAPS-I), sequential organ failure assessment (SOFA), main comorbidities (hypertension, congestive heart failure, cardiac arrhythmias, chronic pulmonary obstructive disease, diabetes mellitus, lymphoma, metastatic cancer, liver disease, obesity) and type of admission (clinical or surgical). Model 3 adjusts for covariates in model 2 and main causes of metabolic alkalosis (diuretic previous or during ICU stay, alkali administration, hypokalemia, hypernatremia, renal replacement therapy and gastric output), minimum serum bicarbonate, partial $\mathrm{CO}_{2}$ pressure $>45 \mathrm{mmHg}$, acute kidney injury severity, mechanical ventilation and hyponatremia during ICU stay. Bias and $95 \% \mathrm{CI}$ were estimated by bootstrap re-sampling. The odds ratio for mortality is displayed for each of $5 \mathrm{mEq} / \mathrm{L}$ in serum bicarbonate All $p$ values $<0.0001$ 